\title{
Pengembangan Virtual Laboratory Berbasis Pendekatan Saintifik Pada Mata Pelajaran Biologi Untuk Siswa SMA
}

\author{
Dina Liana $^{1^{*}, \text { Nova Adi Kurniawan }}{ }^{2}$ \\ 1,2,) Jurusan Pendidikan Guru Madrasah Ibtidaiyah, STAI Auliaurrasyidin, Tembilahan, Indonesia
}

Pengiriman: 17 Oktober 2018; Diterima: 1 Nopember 2018; Publikasi: Nopember 2018

\begin{abstract}
This research is to describe the result of the development of scientific based virtual laboratory for Biology subject at Senior High Schools, Indragiri Hilir, Riau. The type of this research is research and development $(\mathrm{R} \& \mathrm{D})$, which intentionally and systematically is to discover, formulate, fix, develop, produce, test product efectivity, model, method/ strategy, service, certain superior procedures, the latest, effective, efficience, productive, and meaningful. The results of the research prove the use of scientific based virtual laboratory is practically employed for teacher (3.5) and students $(3,28)$, validity (3.20), and effectiveness (70.7). Accordingly, virtual laboratory plays a vital role to overcome limited laboratory as a learning resources. Besides, virtual laboratory is one of effective learning media - illusion laboratory - which helps students in practical work so they achieve a good competence.
\end{abstract}

\section{Keywords: Virtual Laboratory, Scientific, Biology}

ABSTRAK: Tujuan penelitian ini adalah untuk mendeskripsikan hasil pengembangan virtual laboratory berbasis pendekatan saintifik untuk mata pelajaran Biologi di SMA Kabupaten Indragiri Hilir Provinsi Riau. Jenis penelitian ini adalah research and development $(R \& D)$ yang secara sengaja, sistematis,

bertujuan/diarahkan untuk mencari temuan, merumuskan, memperbaiki, mengembangkan, menghasilkan, menguji keefektifan produk, model, metode/strategi/cara, jasa, prosedur tertentu yang lebih unggul, baru, efektif, efisien, produktif, dan bermakna. Hasil penelitian ini menunjukkan bahwa penggunaan virtual laboratory berbasis pendekatan saintifik dinilai sangat praktis untuk guru $(3,5)$ dan untuk siswa $(3,28)$, dengan tingkat validitas $(3,20)$ dan tingkat keefektifan penggunaan produk dengan nilai $(70,7)$. Dari hasil tersebut dapat disimpulkan bahwa dengan kehadiran Virtual laboratory sangat berperan baik untuk mengatasi keterbatasan labor sebagai sumber daya pembelajaran, selain itu Virtual Laboratory juga merupakan salah satu media pembelajaran yang efektif mengingat fungsinya sebagai laboratorium maya yang sangat membantu peserta didik dalam pelaksanaan praktikum sehingga mampu mencapai kompetensi yang baik.

Kata Kunci: Virtual Laboratory, Saintifik, Biologi

*Penulis Korespondensi:

Alamat surel: dinaliana2211@ gmail.com 


\section{PENDAHULUAN}

Pembelajaran Biologi dalam pedoman pengembangan kurikulum 2013 menyebutkan bahwa di tingkat SMA pembelajaran dilaksanakan dengan berbasis keterpaduan, Pembelajaran Biologi bukan hanya sebagai disiplin ilmu, tetapi dikembangkan sebagai mata pelajaran integrative science. Integrative science mempunyai makna memadukan berbagai aspek yaitu domain sikap, pengetahuan, dan keterampilan.

Praktikum memberikan kesempatan kepada peserta didik untuk memenuhi dorongan rasa ingin tahu dan membantu peserta didik dalam menemukan pengetahuan melalui eksplorasinya terhadap alam. Melalui kegiatan praktikum peserta didik dapat memperoleh pengalaman mengidentifikasi masalah yang nyata, serta merumuskannya secara operasional, merancang cara terbaik untuk memecahkan masalahnya dan mengimplementasikannya dalam laboratorium, serta menganalisis dan mengevaluasi hasilnya.

Berdasarkan wawancara dengan guru dan peserta didik diperoleh informasi bahwa guru masih menekankan pada penilaian kognitif saja. Tidak terlaksananya kegiatan praktikum menyebabkan terkendalanya pengembangan pengetahuan dan kemampuan mengidentifikasi masalah yang nyata pada peserta didik. Namun kita ketahui bahwa pengadaan laboratorium dibutuhkan waktu yang cukup lama, sehingga Virtual laboratory menjadi salah satu alternatif untuk mengembangkan pengetahuan peserta didik.

Untuk mengatasi kendala dalam pelaksanaan praktikum tersebut kehadiran teknologi masa kini seperti vitrual laboratory sangat membantu dalam pembelajaran Biologi.
Virtual laboratory merupakan lingkungan belajar alternatif yang dapat membantu peserta didik untuk mengatasi keterbatasan fasilitas laboratorium (Tatly \& Ayas, 2011: 159).

Salah satu pendekatan yang dapat menunjang peserta didik untuk berfikir kritis adalah pendekatan saintifik. Pendekatan saintifik memiliki 5 fase yaitu, mengamati, menanya, mengumpulkan informasi, menalar dan mengkomunikasikan. Dari 5 fase tersebut dapat mengembangkan berbagai skill seperti keterampilan berpikir kritis (critical thinking skill), keterampilan berkomunikasi (communication skill), keterampilan melakukan kerja sama dan penyelidikan (research and collaboration skill) dan perilaku berkarakter, karena pengalaman belajar yang diberikan dapat memenuhi tujuan pendidikan dan bermanfaat bagi pemecahan masalah dan kehidupan nyata (Machin, 2014: 31). Dengan demikian virtual laboratory berbasis pendekatan saintifik dapat membantu peserta didik untuk mengembangkan pengetahuan, keterampilan dan sikap.

Berdasarkan latar belakang di atas dikemukakan tujuan perumusan masalah bagaimanakah hasil pengembangan virtual laboratory berbasis pendekatan saintifik untuk mata pelajaran Biologi di SMA Kabupaten Indragiri Hilir Provinsi Riau?

Penelitian ini bertujuan untuk mendeskripsikan hasil pengembangan virtual laboratory berbasis pendekatan saintifik untuk mata pelajaran Biologi di SMA Kabupaten Indragiri Hilir Provinsi Riau. 


\section{METODE PENELITIAN}

Jenis penelitian ini adalah Research and Development (R\&D). Penelitian ini menggunakan model pengembangan Plomp yang terdiri dari investigasi awal, tahap prototipe dan efektivitas.

\section{HASIL DAN PEMBAHASAN}

Dari hasil tahap investigasi awal didapatkan gambaran bahwa rancangan yang akan dikembangkan oleh peneliti yaitu berupa sumber belajar yang menyediakan kesempatan peserta didik untuk melakukan praktikum dan dapat mengembangkan pengetahuan, sikap dan keterampilan peserta didik. Gambaran tersebut yaitu berupa virtual laboratory berbasis pendekatan saintifik yang dapat memberikan kesempatan kepada peserta didik untuk melakukan praktikum, selanjutnya dari hasil tahap prototype didapatkan praktikalitas virtual laboratory berbasis pendekatan saintifik. Berdasarkan penelitian Jaya (2012: 89) virtual laboratory dapat memfasilitasi pesera didik untuk berfikir kritis. Berikut hasil pengembangan virtual laboratory.

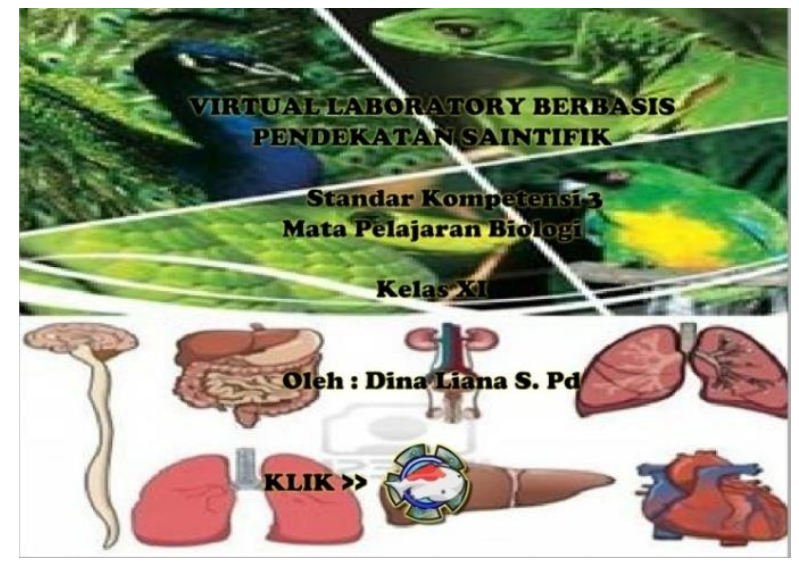

Gambar 1. Tampilan Pembuka / Cover Virtual Laboratory Berbasis Pendekatan Saintifik

Gambar 1 merupakan tampilan pembuka atau cover virtual laboratory berbasis pendekatan saintifik. Pada tampilan pembuka terdapat identitas nama judul pembelajaran, identitas standar kompetensi, identitas mata pelajaran, identitas untuk siapa virtual laboratory berbasis pendekatan saintifik diperuntukkan, identitas pemilik virtual laboratory berbasis pendekatan saintifik, dan adanya petunjuk "klik" tombol untuk memulai kegiatan virtual laboratory berbasis pendekatan saintifik yang beranimasikan Ikan. Pada tampilan pembuka atau cover terdapat gambar hewan seperti katak, ular dan burung selain itu juga terdapat organ-oragan seperti. 1. Organ pencernaan yaitu hati, lambung, pankreas, usus besar dan usus halus, 2. Organ pernapasan yaitu paru-paru, dan 3. Organ ekskresi yaitu ginjal. Penggunaan gambar hewan dan organ-organ tersebut merupakan gambaran materi standar kompetensi 3

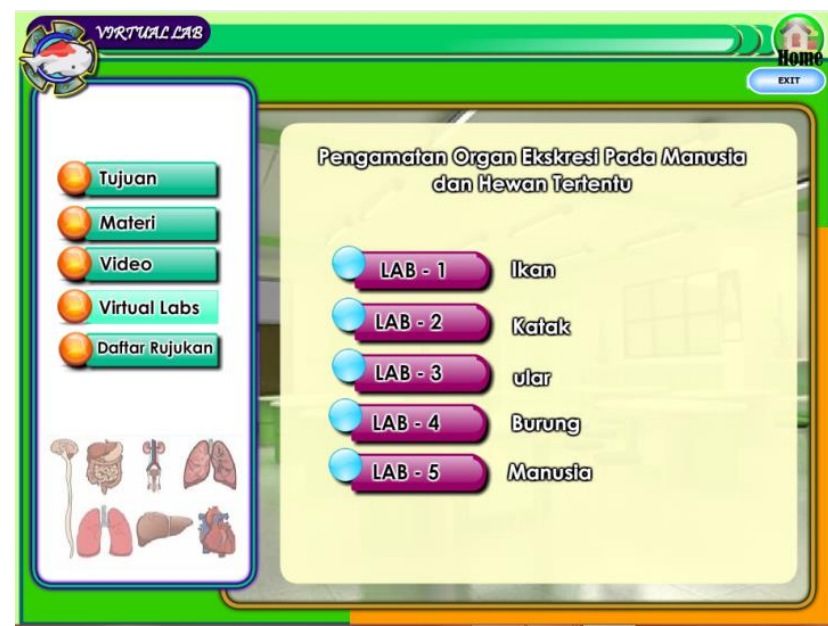

Gambar 2. Aktivitas Virtual Laboratory Berbasis Pendekatan Saintifik

Gambar 2 merupakan tampilan aktivitas virtual laboratory berbasis pendekatan saintifik. Tampilan aktivitas terdapat tombol navigasi lab 1 
sampai lab 5, tombol lab tersebut merupakan tombol untuk masing-masing praktikum yang akan dilakukan. Pada tampilan slide aktivitas terdapat tombol home disudut kanan atas yang beranimasikan rumah, terdapat tombol navigasi (Tujuan, Materi, Video, Virtual Lab, dan Daftar rujukan), terdapat gambar organ-organ dalam pada sudut kiri bawah dan pada tampilan slide terdapat beberapa kombinasi warna.

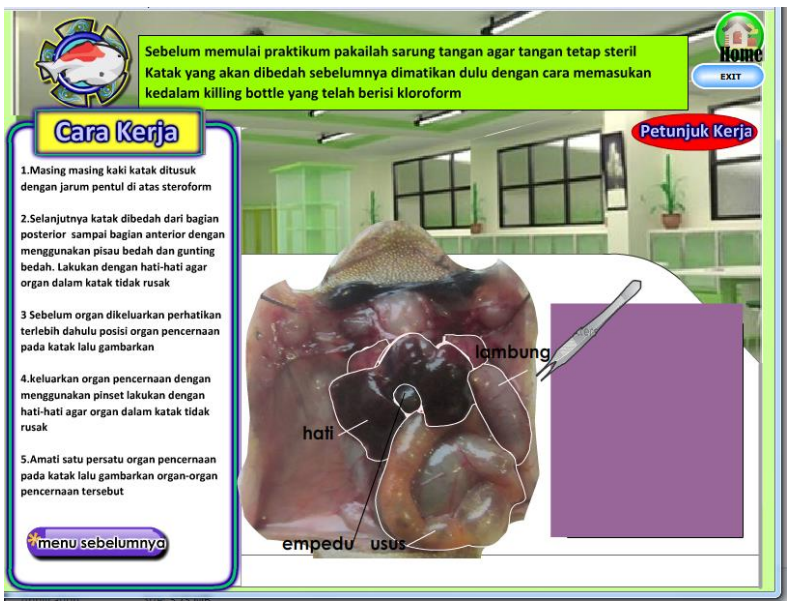

Gambar 3. Kegiatan praktikum pembedahan katak yang dilengkapi dengan cara kerja.

Gambar 3 merupakan tampilan video virtual laboratory berbasis pendekatan saintifik yang menampilkan kegiatan pembedahan hewan, bertujuan untuk memberikan pengetahuan mengenai cara memmbedah hewan dan untuk mengetahui bagian-bagian organ apa saja yang terdapat pada hewan yang dibedah, selain itu bertujuan untuk menambah pengetahuan peserta didik yang mengikuti kegiatan praktikum virtual tersebut dan merupakan salah satu dari fase pendekatan saintifik yaitu fase mengamati

Virtual laboratory berbasis pendekatan saintifik dinilai sangat praktis oleh guru berikut tabel mengenai data hasil praktikalitas Virtual Laboratory pendekatan saintifik oleh guru.
Tabel 1. Data Hasil Praktikalitas Virtual Laboratory Berbasis Pendekatan Saintifik oleh Guru.

\begin{tabular}{|r|c|c|c|c|}
\hline $\begin{array}{c}\mathbf{N} \\
\mathbf{O}\end{array}$ & $\begin{array}{c}\text { Aspek } \\
\text { Penilaian }\end{array}$ & $\begin{array}{r}\text { Rat } \\
\text { a-rata }\end{array}$ & $\begin{array}{c}\text { Kriteri } \\
\mathbf{a}\end{array}$ & $\begin{array}{c}\text { Kategor } \\
\mathbf{i}\end{array}$ \\
\hline 1. & $\begin{array}{c}\text { Kemudaha } \\
\text { n dipelajari }\end{array}$ & 3,4 & $\begin{array}{c}\text { Sangat } \\
\text { Tinggi }\end{array}$ & $\begin{array}{c}\text { Sangat } \\
\text { Praktis }\end{array}$ \\
\hline 2. & Efisiensi & 3,6 & $\begin{array}{c}\text { Sangat } \\
\text { Tinggi }\end{array}$ & $\begin{array}{c}\text { Sangat } \\
\text { Praktis }\end{array}$ \\
\hline 3. & $\begin{array}{c}\text { Dapat } \\
\text { diingat }\end{array}$ & 3,7 & $\begin{array}{c}\text { Sangat } \\
\text { Tinggi }\end{array}$ & $\begin{array}{c}\text { Sangat } \\
\text { Praktis }\end{array}$ \\
\hline 4 & Kesalahan & 3,30 & Tinggi & $\begin{array}{c}\text { Sangat } \\
\text { Praktis }\end{array}$ \\
\hline Rata-rata & $\mathbf{3 , 5}$ & Tinggi & $\begin{array}{c}\text { Sangat } \\
\text { Praktis }\end{array}$ \\
\hline
\end{tabular}

Berdasarkan data hasil praktikalitas pada

Tabel 1 diketahui bahwa kemudahan dipelajari, efisiensi, dapat diingat dan kesalahan oleh guru diperoleh rata-rata 3,5 dengan kriteria tinggi sehingga mendapatkan kategori sangat praktis, karena virtual laboratory berbasis pendekatan saintifik mudah digunakan karena mempunyai petunjuk kerja, sangat menghemat waktu dan tidak mudah error pada saat penggunaan serta dapat digunakan untuk menunjang efektifitas pembelajaran mata pelajaran Biologi. Ini berarti virtual laboratory berbasis pendekatan saintifik yang digunakan sebagai sumber belajar praktis untuk digunakan oleh Guru dalam proses pembelajaran karena memenuhi aspek praktikalitas, seperti kemudahan untuk penggunaan sebagai sumber belajar yang tepat. Hal ini dikarenakan pada virtual laboratory berbasis pendekatan saintifik mempunyai petunjuk kerja yang jelas, waktu yang diperlukan dalam pelaksanaan singkat cepat dan tepat. Menurut Rodrigues dan Tekdal dalam Tuysuz (2010: 40) virtual laboratory memiliki keunggulan dalam 
pemanfaatan pembelajaran seperti dari segi waktu, keamanan dan biaya.

Selanjutnya virtual laboratory berbasis pendekatan saintifik bermanfaat dalam menunjang peserta didik untuk mengembangkan pengetahuan, sikap dan keterampilan peserta didik. Hal ini dapat dilihat pada table berikut.

Tabel 2. Data Hasil Praktikalitas Virtual Labatory Berbasis Pendekatan Saintifik oleh Peserta didik

\begin{tabular}{|c|l|c|c|c|}
\hline $\begin{array}{c}\text { N } \\
\text { o }\end{array}$ & \multicolumn{1}{|c|}{$\begin{array}{c}\text { Aspek } \\
\text { Penilaian }\end{array}$} & $\begin{array}{c}\text { Rata } \\
\text {-rata }\end{array}$ & $\begin{array}{c}\text { Kriteri } \\
\mathbf{a}\end{array}$ & Kategori \\
\hline 1 & $\begin{array}{l}\text { Kemudahan } \\
\text { Penggunaan }\end{array}$ & 3,30 & $\begin{array}{c}\text { Sangat } \\
\text { Tinggi }\end{array}$ & $\begin{array}{c}\text { Sangat } \\
\text { Praktis }\end{array}$ \\
\hline 2 & $\begin{array}{l}\text { Penggunaan } \\
\text { Waktu }\end{array}$ & 3,24 & Tinggi & Praktis \\
\hline 3 & $\begin{array}{l}\text { Manfaat } \\
\text { Penggunaan }\end{array}$ & 3,30 & Tinggi & Praktis \\
\hline \multicolumn{2}{|c|}{ Rata-rata } & $\mathbf{3 , 2 8}$ & Tinggi & Praktis \\
\hline
\end{tabular}

Berdasarkan data hasil praktikalitas pada Tabel 2 diketahui bahwa kemudahan penggunaan, penggunaan waktu dan manfaat penggunaan oleh peserta didik diperoleh rata-rata 3,28 dengan kriteria tinggi sehingga mendapatkan kategori praktis. Hal ini dikarenakan pada virtual laboratory berbasis pendekatan saintifik mudah digunakan dan bermanfaat untuk mengembangkan pengetahuan, keterampilan dan sikap karena pada virtual laboratory terdapat fase-fase pendekatan saintifik.

Media yang digunakan sebagai sumber belajar praktis untuk digunakan dalam proses pembelajaran karena memenuhi aspek praktikalitas dalam hal kemudahan untuk penggunaan sebagai sumber belajar yang tepat, dan dapat digunakan oleh peserta didik karena pada virtual laboratory berbasis pendekatan saintifik terdapat petunjuk kerja yang jelas sehingga peserta didik tidak mengalami kebingungan pada saat melakukan kegiatan virtual dan dapat memahami materi pelajaran serta dapat mengembangkan pengetahuan sikap dan keterampilan. Menurut Rusman (2012:167) virtual laboratory harus benar-benar dapat digunakan atau diterapkan dalam pembelajaran, sehingga dapat menambah pemahaman dan meningkatkan kualitas pembelajaran.

Selanjutnya waktu yang diperlukan dalam pelaksanaan singkat cepat dan tepat sehingga peserta didik dapat mengatur kecepatan belajar sesuai dengan kemampuan peserta didik dan virtual laboratory berbasis pendekatan saintifik sangat bermanfaat bagi peserta didik untuk memperoleh pengalaman belajar secara nyata, peserta didik dapat berkonsentrasi penuh dalam belajar dan dapat melatih peserta didik untuk belajar secara mandiri sehingga virtual laboratory berbasis pendekatan saintifik dapat dimanfaatkan sebagai penunjang untuk mengembangkan pengetahuan, sikap dan keterampilan peserta didik. Hal ini dikarenakan pada virtual laboratory terdapat aktivitas praktikum virtual yang dapat memberikan pengalaman belajar secara nyata kepada peserta didik. Menurut Nasution (2011: 205) pengalaman belajar virtual laboratory berbasis pendekatan saintifik yang dikembangkan dapat membantu peserta didik untuk mencapai tujuan pembelajaran seefektif dan seefisien mungkin, serta memungkinkan peserta didik untuk 
melakukan pembelajaran secara aktif, tidak sekedar membaca dan mendengar saja.

Tujuan utama virtual laboratory adalah memberikan pengalaman belajar untuk mendukung keterlaksanaan percobaan yang dilakukan dilaboratorium nyata, sehingga peserta didik dapat meningkatkan efektivitas di laboratorium (Domingues, 2010: 23).

Selain pengalaman belajar dan melatih peserta didik untuk belajar secara mandiri, pada virtual laboratory terdapat juga menu materi sehingga peserta didik dapat mengembangkan pengetahuan, sikap dan keterampilan melalui fase mengumpulkan informasi yang terdapat pada pendekatan saintifik. Sesuai dengan penelitian Amelia (2013: 96) bahwa media virtual laboratory menyediakan pengalaman belajar yang nyata bagi peserta didik dan membantu peserta didik untuk berkonsentrasi mengerjakan kegiatan belajar serta secara mandiri dapat menggunakan media ajar.

\section{KESIMPULAN DAN SARAN}

Berdasarkan dari uraian pembahasan dapat disimpulkan bahwa dengan kehadiran Virtual laboratory sangat berperan baik dalam mengatasi keterbatasan labor sebagai sumber daya pembelajaran, selain itu Virtual Laboratory juga merupakan salah satu media pembelajaran yang efektif mengingat fungsinya sebagai laboratorium maya yang sangat membantu peserta didik dalam pelaksanaan praktikum sehingga mampu mencapai kompetensi yang baik.

Bagi peneliti selanjutnya disarankan agar dapat mengembangkan virtual laboratory berbasis pendekatan saintifik yang dapat digunakan secara online dan dapat dioperasikan pada netbook yang mengikuti perkembangan kecanggihan tekhnologi masa kini.

\section{UCAPAN TERIMAKASIH}

Ucapan terima kasih terutama di tujukan kepada Guru dan Peserta Didik SMA di Kabupaten Indragiri Hilir Provinsi Riau yang telah membantu jalannya proses penelitian. Ucapan terima kasih dapat juga disampaiakan kepada pihak-pihak yan membantu pelaksanaan penelitian.

\section{DAFTAR PUSTAKA}

Amelia, T. 2013. Pengembangan Virtual laboratory Pada Materi Bioteknologi Untuk Peserta didik Kelas XII. Thesis. Universitas Negeri Padang.

Domingues, L., I. Rocha., F. Daurado, et al. 2010. Virtual laboratories in (bio) chemical engineering education. Elsevier Education For Chemical Engineers. 5 (2010): e22e27.

Jaya, H. 2012. Pengembangan Laboratorium Virtual Untuk Kegiatan Praktikum Dan Memfasilitasi Pendidikan Karakter Di. Jurnal Pendidikan Vokasi, Vol 2, Nomor 1: 89.

Machin, A. 2014. Implementasi Pendekatan Saintifik, Penanaman Karakter Dan Konservasi Pada Pembelajaran Materi Pertumbuhan. Jurnal Pendidikan BIOLOGI Indonesia. JPII 3 (1): 31.

Nasution. 2010. Berbagai Pendekatan dalam Proses Belajar Mengajar, Jakarta: Bumi Aksara.

Rusman. 2012. Belajar dan Pembelajaran Berbasis Komputer Mengembangkan Profesionalisme Guru Abad 21. Bandung: Alfabeta.

Tatly, Z \& A. AlBiologisa. 2013. Effect of a Virtual Chemistry Laboratory on Students' 
Achievement. Educational Technology \& Society, Vol. 16 (1): 159.

Tuysuz, C. 2010. The Effect of the Virtual laboratory on Students' Achievement and Attitude in Chemistry. International Online Journal of Educational Sciences, ISSN: 1309-2707 VOL, 2 (1) : 39-40. 